\title{
The Consult
}

\section{Based on "The Raven" by Edgar Allen Poe}

\author{
Suni Jani ${ }^{1}$
}

Received: 18 January 2016 / Accepted: 23 March 2016/Published online: 9 May 2016

(C) Academic Psychiatry 2016

Once upon a consult dreary

While I stood there tired and weary

Staring at my patient's door

"Will you feel safe?" I begged, not implored

Quoth my patient "Nevermore!"

Deep into that answer peering, long I stood there wondering, fearing,

Doubting, dreaming dispos no mortal ever dared to dream before;

But the silence was unbroken, and the stillness gave no token,

And the only word there spoken was the whispered word, "Are you sure?"

This I whispered, and an echo murmured back the word, "Nevermore!"-

Merely this and nothing more

Back into the fellows room turning, all my soul within me burning,

Soon again I heard a paging somewhat louder than before.

"Surely," said I, "surely that is a test page at my purse's floor;

Let me see, then, what thereat is, and this mystery explore-

Let my heart be still a moment and this mystery explore;-

'Tis the anxious team! Bah! What a bore!"

Open here I dialed their number, when, with many a flirt and flutter,

Answered a stately intern of the saintly days of yore;

Not the least obeisance made he; not a minute stopped or stayed he;

But, with mien of lord or lady, asked the question of my patience once more "When does he leave?" And nothing more

Beguiling my sad fancy into smiling, To oppose the grave and stern decorum of the countenance he wore,

"Though thy hopes be strong and spoken, thou," I said, "art sure no maven, Ghastly grim and full are the psychiatric havens. I shall place his name in the list's waiting, only this and nothing more!"

"Fine!" Bellowed the intern which shook my core. I called case management and there is nothing more.

Suni Jani

suni.n.jani@gmail.com 